\title{
Asian Miracles and Climate Change
}

\author{
Jan-Erik Lane ${ }^{1} \&$ Florent Dieterlen ${ }^{2}$ \\ ${ }^{1}$ Fellow with Public Policy Institute, BELGRADE; Address: 10 Charles Humbert, 1205 Geneva; 559 A, 3rd \\ Floor, Thuya Street, 9th Quarter, Yangon. Myanmar \\ ${ }^{2}$ Independent scholar, Geneva \\ Corresponding: Jan-Erik Lane, Fellow with Public Policy Institute, BELGRADE; Address: 10 Charles Humbert, \\ 1205 Geneva; 559 A, 3rd Floor, Thuya Street, 9th Quarter, Yangon. Myanmar
}

Received: December 9, 2017

Accepted: December 22, 2017 Online Published: December 25, 2017

doi:10.20849/ajsss.v2i4.261

URL: https://doi.org/10.20849/ajsss.v2i4.261

\begin{abstract}
One may introduce a concept of Hawking irreversibility as the point where temperature has risen so much that the global warming consequences threaten the survival of mankind. The recent news out of China that its CO2s are increasing again makes this term highly policy relevant. Moreover, the methane emissions have started to augment, which also calls up Hawking irreversibility. The drive behind these dire developments is the endless zest for affluence and wealth, fueled by ever larger energy consumption. Asian miracle economies should take this warming seriously and srart the implementatuion os COP21 Treaty.
\end{abstract}

Keywords: decarbonisation, Hawking irreversibility, GHCs, CO2S, methane, COP21 Treaty goals, solar power plants.

\section{Introduction}

Climate scientists warn, already before the implementation of the UNFCCC Agreement from Paris 2015 that the decarbonisation plan decided in global governance will not be enough to stabilize temperature at +2 Celsius, at most. Global average temperature will most probably be larger than the COP21 objective. At what point on the temperature scale, we move into Hawking irreversibility is not known. But a rise beyond +4 degrees will have dramatic consequences for the ecology and human social systems.

A few days before the start of the UN global environment reunion COP23 (6-13 November 2017) in Bonn, the major study Climate Science Special Report: Fourth National Climate Assessment (USGCRP, 2017) https://assets.documentcloud.org/documents/4174364/Climate-Science-Special-Report-2017.pdf) was published in Washington. It examines the global warming problematic from the point of view of the US and the world, based upon years of research by a large group of US scholars. It definitively recommends a combination of national and international policy-making to halt temperature rise, despite the fact that the US government is negative. It renders an impressive list of climate change impacts upon the US territory and points decisively at human causes. We must then ask: Can decarbonisation policies be implemented or managed? The COP23 by the UNFCCC reflects upon the very same problem.

The Asia-Pacific region has taken over economic leadership from the Atlantic region. Some 60 per cent of global GDP comes from the APEC countries. And the Asian members plus India plan large increases in energy consumption up to 2040, but they show little interest in the greenhouse emission problematic, at least not in real action.

All countries in the world have formed a common pool regime (CPR) to save the atmosphere from more GHGs, focusing only upon the $\mathrm{CO} 2 \mathrm{~s}$. The global decarbonisation plan includes:

i) Stall the rise if CO2s by 2020 (GOAL I);

ii) Decreasing the CO2s by $30-40 \%$ by 2030 (GOAL II);

iii) More or less full decarbonisation by around 2075 (GOAL III);

iv) Decentralised implementation under international oversight, financial support and technical assistance.

These are enormous goals, as only one country - Uruguay - is near GOAL I and GOAL II. Can they be implemented? Will the Asian miracle economies implement them? 


\section{Present Global Predicament}

The greenhouse gases (GHG) have a strong anthropogenic sources, being linked with socio-economic development or economic growth via the consumption of energy, especially the burning of fossil fuels, use of cement and emission of methane from land sinks, cows, microbes, etc. The UNFCCC has focused on halting $\mathrm{CO} 2 \mathrm{~s}$ and decreasing them in a gigantic decarbonisation policy globally in this century.

Since 1970, global energy consumption has more than tripped. And the share of Asia has increased phenomenally. The Asian economic miracle started in Japan after the Second War, spread to the four miracles Taiwan, South Korea, Hong Kong and Singapore - only to include mainland China since1980, as well as further widening to all of South East Asia and South Asia plus Kazakhstan (Figure 1)

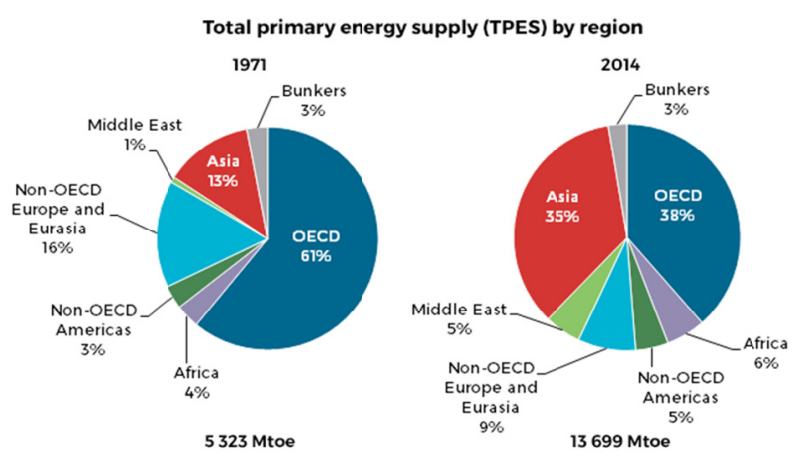

Figure 1. Global energy

This economic revolution has made Asia the set of factories of the world, raising affluence and wealth as well as diminishing poverty. The cost is clear, as the Asian Development Bank states:

Southeast Asia is also becoming a larger contributor to global GHG emissions, with the fastest growth in carbon dioxide emissions in the world between.... Deforestation and land degradation have been driving most of the emissions to date. ... Given the region's vulnerability to climate change, curtailing global emissions growth should be a priority consideration, to which the region can make an important contribution. (ADB, 2015: Foreword)

The ADB has its solution to the energy-emission conundrum, namely carbon capture or sequestration. However, it is a costly and flawed technology for removing CO2s. It pushed the GHG problem to the Earth's crust, but it will not go ways. The same applies to the hope for an environmental Kuznets' curve.

\subsection{No Kuznets' Curve for CO2s}

Figure 2 shows that there is no Kuznets' curve (first rising, then descending) for $\mathrm{CO} 2$ : richer countries emit more $\mathrm{CO} 2$ than poor ones. International aviation is a very major source of $\mathrm{CO} 2$ emissions, and it is booming.

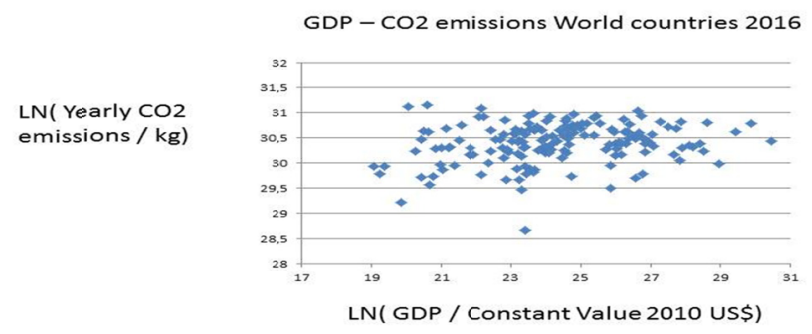

Figure 2. GDP-COP for all countries 
The CO2 emissions go with GDP growth, as the intermediate link is the ever expanding energy demand. Several Asian economies are now either mature, catch-up or taking-off economies (Rostov, 1960; Barro, 1991; Barro, \& Sala-i-Martin, 1992, 1995).

\subsection{Co2 Emissions in Asian Miracles}

Below we look at the GDP and CO2 links in a few major Asian economies.

\subsubsection{Catch-Up Strategy: China}

It is alarming information that China, the biggest emitter of $\mathrm{CO} 2 \mathrm{~s}$, will not succeed to halt its curve for $\mathrm{CO} 2 \mathrm{~s}$. Instead, it counts upon some 3 per cent increases the nearest years - see Figure 3.

GDF - CO2 Emissions for China $1990-2016$

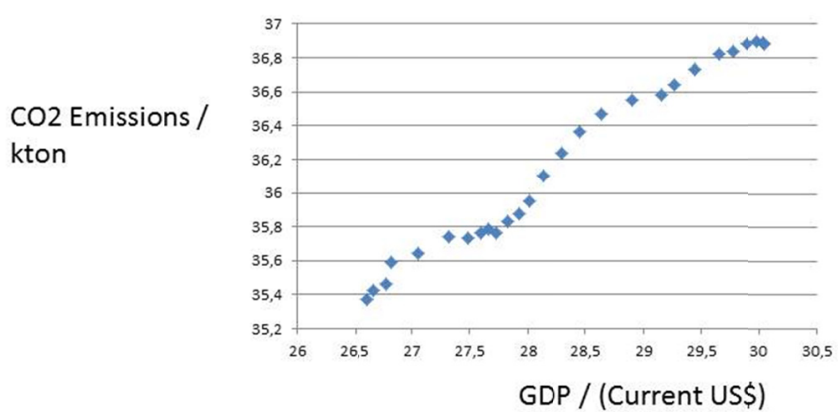

Figure 3. China: GDP and CO2s: $y=0,46 x, R^{2}=0,98$

China has officially declared that it intends to meet both COAL I, halting the increase in CO2s, and GOAL II, reducing $\mathrm{CO} 2 \mathrm{~s}$ by some 30 per cent. But promises and intensions are one thing, real life developments another matter. All countries in this CPR can at any time renege, the US has already done.

China is well wall if huge pollution problem, making Beijing almost inhabitable some days, It invests heavily in both nuclear power and modern renewables. At the same time it keeps up its economic expansion in order to catch-up with the West:

i) Airports and own constructed aircraft;

ii) Biggest car market in the world'

iii) SUVs and ever larger engines;

iv) The New Silk Road: infra-structure expansion into Central Asia and the Middle East.

Air and sea transportation adds much to $\mathrm{CO} 2$ emissions. Even if electrical cars are launched massively in China, one must ask where the electricity comes from. Coal?

\subsubsection{India: Take-Off Strategy}

Its Rostow take-off point in time would 1990, when Nehru's economic regime was abandoned for free market economics. Unleashing the dormant giant of India has led to enormous economic expansion and growth in Co2s - see Figure 4.

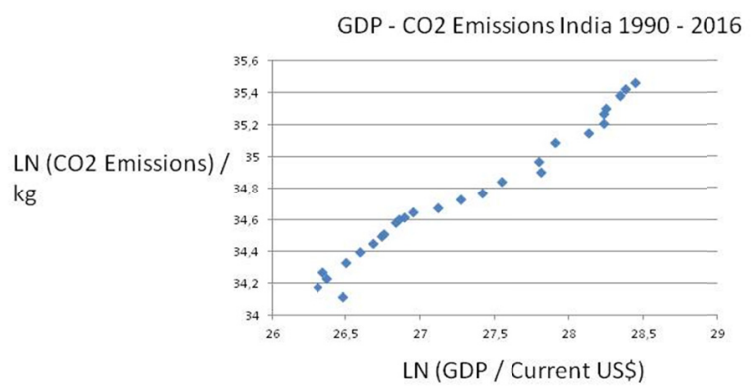

Figure 4. INDIA: GDP and CO2 
India takes the position that any reduction its economic growth due to the fulfillment of global decarbonisation must be compensated by the West. Moreover, the Super Fund should be employed for the energy transformation that is necessary for India to comply with GOAL I and GOAL 2.

As Ramesh (2015) explains, India cannot alone uplift its million poor without coal power. In addition, families in India rely much upon wood and charcoal - traditional renewables. The country is investing in nuclear power and modern renewables. However, its hydro power suffers from water scarcity - a positive feedback loop from climate change.

\subsubsection{South Korea: Mature Economy on Imported Energy}

South Korea is today a member of the club of First Advanced economies, the OECD. From dismal poverty, it has pursued a spectacularly successful catch-up strategy, making it a global leader in technology and car production. The transformation is all the remarkable, as the country possess few internal power resources. Thus, it has relied upon imported fossil fuels, with the result in Figure 5, huge CO2 emissions.

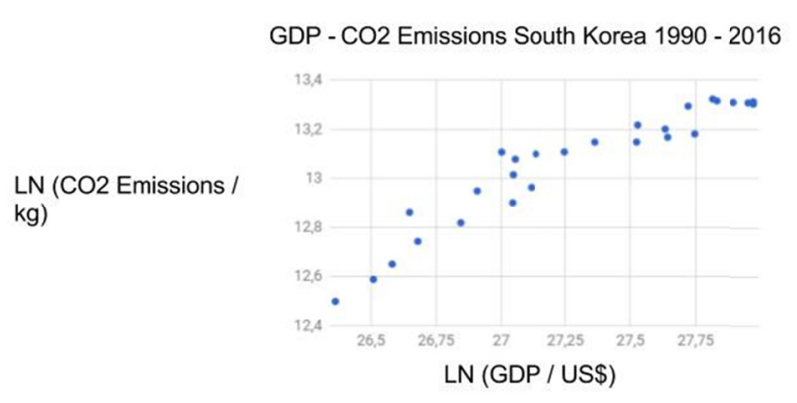

Figure 5. South Korea

To come to grips with its enormous GHG emissions, South Korea has attempted to reduce its coal dependency. Thus, it engaged upon a most ambition nuclear program, as its force is the largest power source in the world. South Korea with its advanced technology can build new and better as well as safer atomic power plants, also constructing them abroad. But the new president hesitates about nuclear power, like the European governments, and has launched a new energy strategy based upon natural gas, imported mainly from Australia and Indonesia. But it will still result in $\mathrm{CO} 2$ emissions higher than GOAL II in CO21.

\subsubsection{Iran: Sleeping Giant}

Iran has had several take-off points in time, but these occasions have been arrested by political reversals. Now, Iran prepares its strategy of catch-up, first with the Sunni Arab world and later with the West. Energy in Iran is all about fossil fuels: oil and gas. And the CO2s are high for Iran - Figure 6.

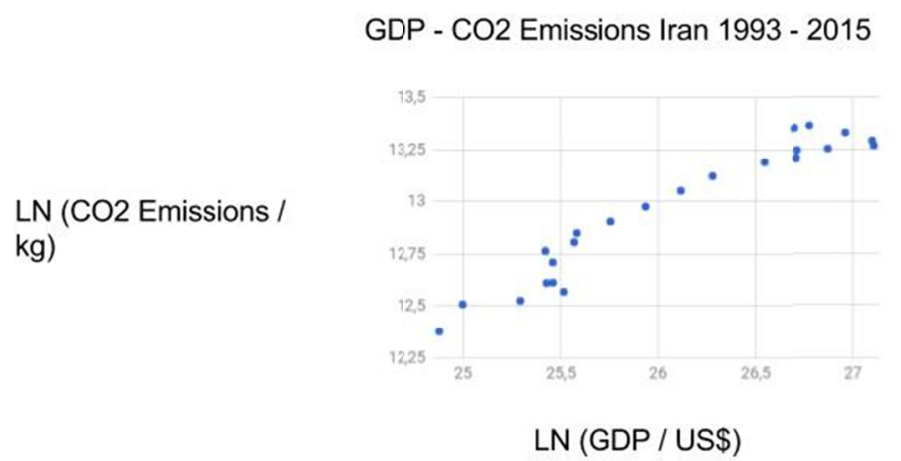

Figure 6. Iran 
Iran will have to renege on COP21 objectives, unless receiving support from outside. The solution is apparent: solar power parks.

To Sum Up: The Asia-Pacific region has become dominant in the world economy. This has made Asian countries vulnerable to the threat of global warming from the emissions of GHGs. Asian economies produce a lot of $\mathrm{CO} 2 \mathrm{~s}$, which is why they must be active in the UN global decarbonisation plan: COP21 Treaty. The ADB solution of carbon sequestration is not in the cards of the UNFCCC.

\subsection{Evolving Methane Threat}

We employ the general formula: $\mathrm{dT}=\lambda * \mathrm{dF}$, where ' $\mathrm{dT}$ ' is the change in the Earth's average surface temperature, ' $\lambda$ ' is the climate sensitivity, usually with degrees Celsius per Watts per square meter $(\mathrm{C} /[\mathrm{W} / \mathrm{m} 2])$, and ' $\mathrm{dF}$ ' is the radiative forcing. To get the calculations going, we start from lambda between 0.54 and 1.2, but let's take the average $=0.87$. Thus, we have the formula (Myhre el al, 1998): Formula: (1) $0.87 \times 5.35 \times \ln (C / 280)$.

Figure 7 shows how $\mathrm{CO} 2$ emissions may raise temperature to $4-5$ degrees:

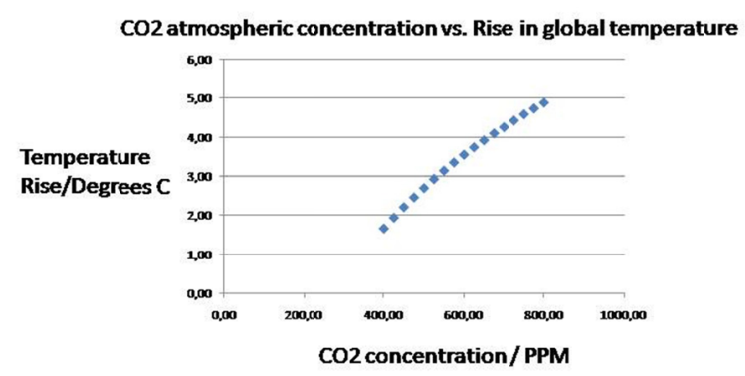

Figure 7. $\mathrm{CO} 2 \mathrm{~s}$ and temperature rise in Celsius

There are several greenhouse gases, but the two biggest are the $\mathrm{CO} 2 \mathrm{~s}$ and methane. The UNFCCC has concentrated upon halting and reducing carbon dioxide, but now we are about to face a methane threat. We shall use the methane concentration curve from mid-2013 to beginning of 2017 issued by NOAA ESRL https://www.esrl.noaa.gov/gmd/ccgg/trends_ch4/, gently suggested by Dlugokencky and Kuniyuki. Why mid 2013? Because it is the last maximum of the second derivative before 2017. Since then, the curve is approximately linear, and we will derive its equation hereunder.

Why should we start with a linear approximation, the simplest approximation that can be found? Because it is a mean between two extreme scenarios:

1) Another plateau like during the years 1999-2006 (probably due to an enhancement in methane transport insulation in ex-USSR after 1991, Pearce), unlikely for the following reasons. Any decrease in methane concentration is very unlikely, as the main sources (in decreasing importance order) generally increase:

a) Agriculture emissions increase with the increase of population, the increase in meat diet in developing countries and the temperature increasing the metabolism of microbes in rice agriculture.

b) Wetlands emissions don't diminish yet, as the microbial chemical activity will increase with temperature for many years.

c) Fossil fuel production and use doesn't diminish yet, and was underestimated by industry (Fred Pearce, http://e360.yale.edu/features/methane_riddle_what_is_causing_the_rise_in_emissions ).

d) Biomass burning doesn't diminish yet, therefore the primary forest diminishes in the tropics, leading also to a decrease in animal, vegetal and cultural (Indigenous People) diversities and an increase in biosphere entropy.

e) Other natural emissions

The most important contribution to the recent rise of methane concentration is mainly due to the increase in activity by microbes, present in points a), b) and d) (Nisbet, in the above reference), mainly in the tropics. This study suggests the positive feedback of the chemical increase of activity of microbes is starting now, yielding a quasi-exponential curve in the near future, or at least a steeper curve. 
We will derive examples of future increase in methane concentration due to such a positive feedback, in addition to a linear approximation. For this, we will not simulate differential equations, which would be the best option, but simulate the hypothetical solution of a transition (bifurcation) between 2 steady-states, with a S-shaped function (which approximate the bifurcation between 2 steady-states) multiplied (to have continuity) by the linear approximation. We shall approximate the S-shape curve by an transitory ( 5 years) exponential curve in continuity with the linear approximation.

The present (November 2017) quasi-linear curve starts mid 2013 (2013.5) and its ordinate is approximately 1813 ppb. We will use as a last value at start of 2017 (2017), and the function is approximately $1846 \mathrm{ppb}$. a straightforward calculation gives the slope: it is approximately $10 \mathrm{ppb} /$ year. Therefore the equation for the future curve if there is no vicious circle (positive feedback) is: $(2) \mathrm{y}=10(\mathrm{t}-2013.5)+1813$, where $t$ is the time when one wants to know the $\mathrm{CH}_{4}$ concentration, and y is the future $\mathrm{CH}_{4}$ concentration in ppb. From this equation, one can estimate the approximate the temperature rise due by methane, by applying to $y$ the formula (1), and multiply it by 25. It will be valid for close future, but will probably be underestimated for farther future, where it will probably closer to an exponential.

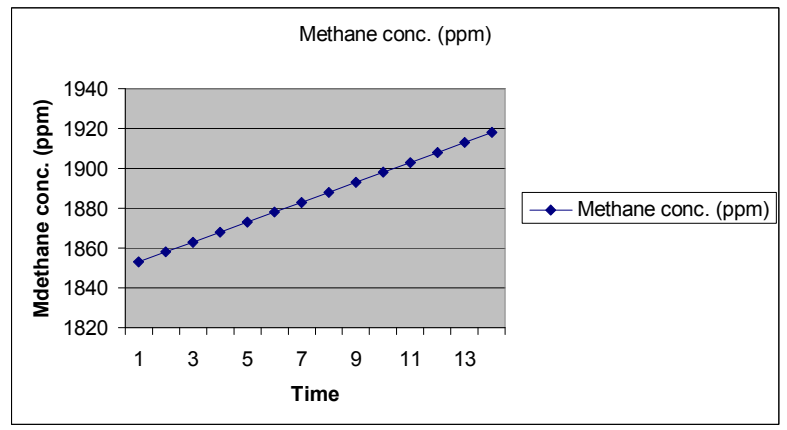

Diagram 1. Projected increase in methane

\subsection{Management Strategies for Decarbonisation}

The UNFCCC suggests a decentralized management strategy for decarbonisation. Reflecting the enormous differences in available energy resources in the member states of COP21 Treaty, each government must develop a strategy for achieving Goal I, Goal II and Goal III. The COP may wish to concentrate upon the following measures start credible decarbonisation:

1) Phasing out coal power plants; convincing a few countries like India and Australia not to build new ones;

2) Replace wood coal with natural gas - small or large scale, stopping deforestation and the use of charcoal in households in poor nations;

3) Turn some countries away from massive dam constructions towards solar power parks, like Brazil and India, as the environmental damages are too big;

4) Help some countries maintain their huge forests: Brazil, Indonesia, Malaysia, Russia, Kongo, India, etc;

5) Abstain from expensive and unsafe carbon sequestration techniques in favour of electricity: solar power and electrical vehicles.

6) The promise of financial support - Super Fund -has to be clarified about both funding and budgeting. A management structure has to be introduced for oversight of the entire decarbonisation process. As the emission of methane increases, the reduction of $\mathrm{CO} 2 \mathrm{~s}$ is all the more important, if irreversibility is to be avoided with a margin.

7) The resort to atomic power plants is highly contested. Nuclear power gets safer and safer, but the problem of storing the used uranium has no solution. If global warming becomes really bad, all these radioactive materials could be released back in our social systems and nature. Some countries expand atomic energy, whereas others dismantle it.

8) Massive construction of solar power and wind power plants in all countries, as well as stimulate small scale solar power; Solar power parks: How many would be needed to replace the energy cut in fossil fuels and maintain the same energy amount, for a few selected countries with big $\mathrm{CO} 2$ emissions? Table 1 has the answer. 
Table 1. Number of Ouarzazate plants necessary in 2030 for COP21's GOAL II: (Note: Average of 250 - 300 days of sunshine used for all entries except Australia, Indonesia, and Mexico, where 300 - 350 was used).

\begin{tabular}{|c|c|c|c|}
\hline Nation & $\begin{array}{l}\text { Co2 reduction pledge / } \\
\% \text { of } 2005 \text { emissions }\end{array}$ & $\begin{array}{l}\text { Number of gigantic solar plants } \\
\text { needed (Ouarzazate) }\end{array}$ & $\begin{array}{l}\text { Gigantic plants needed } \\
\text { for } 40 \% \text { reduction }\end{array}$ \\
\hline China & None (Note 1) & 0 & 3300 \\
\hline India & None ${ }^{(\text {Note 2) }}$ & 0 & 600 \\
\hline Japan & 26 & 460 & 700 \\
\hline South Korea & 37 & 260 & 280 \\
\hline Philippines & 70 & 70 & 40 \\
\hline Turkey & 21 & 60 & 120 \\
\hline Indonesia & 29 & 120 & 170 \\
\hline Saudi Arabia & none $e^{(\text {Note 2) }}$ & 0 & 150 \\
\hline Iran & $4-12^{(\text {Note } 4)}$ & 22 & 220 \\
\hline Kazakhstan & none ${ }^{(\text {Note 2) }}$ & 0 & 100 \\
\hline Turkey & 21 & 60 & 120 \\
\hline Thailand & $20-25^{\text {(Note } 4)}$ & 50 & 110 \\
\hline Malaysia & none $\mathrm{e}^{\text {(Note 2) }}$ & 0 & 80 \\
\hline Pakistan & none ${ }^{(\text {Note 2) }}$ & 0 & 60 \\
\hline Bangladesh & 3,45 & 2 & 18 \\
\hline Australia & $26-28$ & 130 & 190 \\
\hline World & $\mathrm{N} / \mathrm{A}$ & $\mathrm{N} / \mathrm{A}$ & 16000 \\
\hline
\end{tabular}

Notes:

(Note 1) The United States has pulled out of the deal; ${ }^{\text {(Note 2) }}{ }^{\text {No absolute target; }}{ }^{\text {(Note } 3)}$ Pledge is above current level,

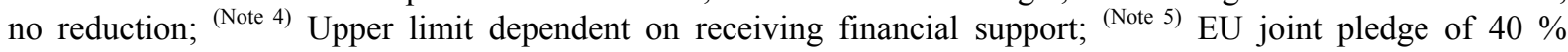
compared to 1990

\section{Conclusion}

We are not yet at the point of Hawking irreversibility, meaning there are still a few degrees of freedom for government policy-making and international governance. The plans of the UNFCCC must be implemented by all nations: Goal I: halting CO2 growth, Goal II: reducing CO2s until 2030 and Goal III: near complete decarbonisation by 2075 .

The Asian economic miracle can run into mega pollution from GHGs. I would undo the immense advances the recent decades. Solar panel parks is the reply, and not carbon capture. 


\section{References}

\section{Sources: Solar power}

EDGAR v 4.3.2, European Commission, Joint Research Centre (JRC)/PBL Netherlands Environmental Assessment Agency. Emission Database for Global Atmospheric Research (EDGAR), release version 4.3.2. http://edgar.jrc.ec.europe.eu, 2016 forthcoming

Janssens-Maenhout, G., Crippa, M., Guizzardi, D., Muntean, M., Schaaf, E., Olivier, J.G.J., Peters, J.A.H.W., Schure, K.M.: Fossil CO2 and GHG emissions of all world countries, EUR 28766 EN,Publications Office of the European Union, Luxembourg, 2017, ISBN 978-92-79-73207-2, doi:10.2760/709792, JRC107877. World Bank Data Indicators, http://data.worldbank.org

Paris 2015: Tracking country climate pledges. Carbon Brief, https://www.carbonbrief.org/paris-2015-tracking-country-climate-pledges

$\mathrm{CO} 2$ Emission Reduction With Solar

http://www.solarmango.com/in/tools/solar-carbon-emission-reduction

\section{GDP sources:}

World Bank national accounts data - data.worldbank.org

OECD National Accounts data files

\section{GHG and energy sources:}

World Resources Institute CAIT Climate Data Explorer - cait.wri.org

EU Joint Research Centre Emission Database for Global Atmospheric

Research - http://edgar.jrc.ec.europa.eu/overview.php

UN Framework Convention on Climate Change -

http://unfccc.int/ghg_data/ghg_data_unfccc/time_series_annex_i/items/3814.php

International Energy Agency. Paris.

Energy Information Administration. Washington, DC.

BP Energy Outlook 2016.

EU Emissions Database for Global Research EDGAR, http://edgar.jrc.ec.europa.eu/

World Bank Data Indicators, data.worldbank.org

British Petroleum Statistical Review of World Energy 2016

\section{Literature}

Asian Development Bank. (2015). Southeast Asia and the economics of global climate stabilization. Mandaluyong City, Philippines: Asian Development Bank,

Barro, R.J. (1991). Economic Growth in a Cross Section of Countries. The Quarterly Journal of Economics, 106(2), 407-443. https://doi.org/10.2307/2937943

Barro, R.J., \& Xavier, X. Sala-i-Martin. (1992). Convergence. Convergence. Journal of Political Economy, 100(2), 223-251. https://doi.org/10.1086/261816

Barro, R.J., \& Xavier,X. Sala-i-Martin. (1995). Economic Growth. McGrow Hill.

Climate Science Special Report: Fourth National Climate Assessment (USGCRP, 2017) https://assets.documentcloud.org/documents/4174364/Climate-Science-Special-Report-2017.pdf)

Conka, K. (2015). UN Unfinished Foundation. The United Nations and Global Environmental Governance. Oxford: OUP.

Kaya, Y., \& Yokoburi, K. (1997). Environment, energy, and economy: Strategies for sustainability. Tokyo: United Nations University Press.

Myhre, G., Highwood, E.J., Shine, K.P. and Stordal, F. (1998). New estimates of radiative forcing due to well mixed greenhouse gases. Geophysics Research Letters, 25(14), 2715-2718

Ostrom, E. (1990). Governing the Commons. Cambridge: Cambridge U.P. 
Ramesh, J. (2015). Green Signals: Ecology, Growth and Democracy in India (2015). Oxford : Oxford University Press.

Rostow, W. W. (1960). The Stages of Economic Growth: A Non-Communist Manifesto. Cambridge: Cambridge University Press.

Sachs, J.D. (2015). The Age of Sustainable Development. New York: Columbia University Press.

Stern, N. (2007). The Economics of Climate Change. Oxford: OUP.

Stern, N. (2015). What are we waiting for? Cambridge, MA: MIT Press.

Vogler, J. (2016). Climate Change in World Politics. Basingstoke: MacmillanPalgrave

\section{Notes}

Note 1. No absolute target.

\section{Copyrights}

Copyright for this article is retained by the author(s), with first publication rights granted to the journal.

This is an open-access article distributed under the terms and conditions of the Creative Commons Attribution license (http://creativecommons.org/licenses/by/4.0/). 